\title{
EDITORIAL
}

\section{Change in editorship}

\author{
Marion Hertel • Werner Weppner
}

(C) Springer-Verlag 2009

Wing Fong Chu
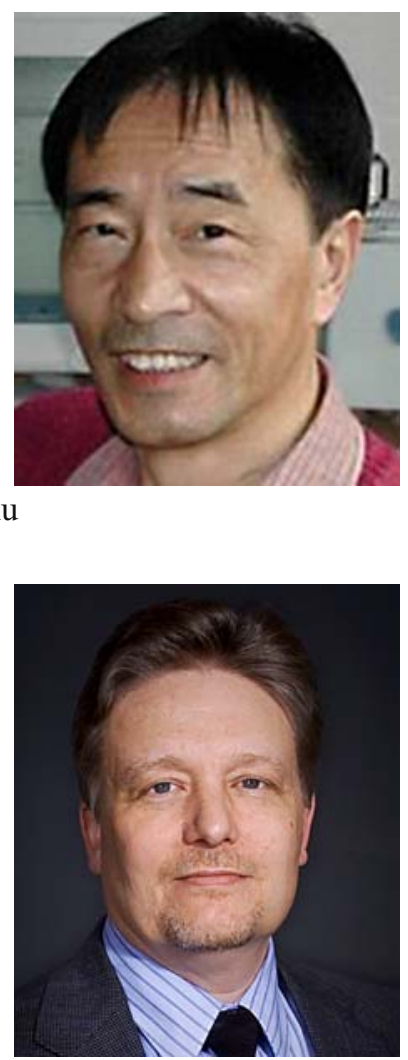

Eric D. Wachsman

M. Hertel ( $\square)$

Springer, Executive Editor Chemistry,

Tiergartenstr. 17,

69121 Heidelberg, Germany

e-mail: marion.hertel@springer.com

W. Weppner

Technische Fakultät, Christian-Albrechts-Universität,

Kaiserstr. 2,

24143 Kiel, Germany

Herewith we are informing you about the change in editorship of our journal Ionics.

Dr. Wing Fong Chu has been Editor-in-Chief of the journal Ionics since the beginnings in 1994. Now, at the time of his retirement from his University position, he moved his activities to private life and left his duties for the journal to a younger colleague. This is an opportunity to thank Wing Fong for his dedication to the field and the journal Ionics. He liked to work quietly and thoroughly. $\mathrm{He}$ was not in need of large public visibility, but he was not second to anybody else with regard to his deep understanding of solid state ionics.

Wing Fong has contributed in a major way to the organization of many conferences, especially the 11 EuroConferences on Solid State Ionics which have been the origin of the journal Ionics. His Editorial work has had a major influence on the continuing success of the journal.

Wing Fong has been a wonderful colleague and friend. With great appreciation for his important contributions to the journal we wish him good luck and satisfaction in his future private life.

We are very pleased that we have gained Eric D. Wachsman as the second Editor-in-Chief of Ionics. Dr. Wachsman is the Director of the Florida Institute for Sustainable Energy, Director of the U.S. Department of Energy High Temperature Electrochemistry Center at the University of Florida, and the Rhines Chair Professor of the Department of Materials Science \& Engineering. He received his Ph.D. in Materials Science \& Engineering from Stanford University, and his B.S. in Chemical Engineering from the University of California at Berkeley. Prior to coming to the University of Florida, Dr. Wachsman rose through the ranks from Post-doctorate to Senior Scientist at SRI International. 
Dr. Wachsman has focused his career on developing advanced, efficient energy conversion devices and technologies. His research is on ionic transport in solids and the heterogeneous electrocatalysis at their surface. This research includes the development of solid oxide fuel cells (SOFC), gas separation membranes, solid-state gas sensors, the electrocatalytic conversion of $\mathrm{CH}_{4}$, and the postcombustion reduction of $\mathrm{NO}_{\mathrm{x}}$ using advanced ion conducting materials.

Dr. Wachsman is a Fellow of the Electrochemical Society in 2007, recipient of the Rhines Chair Endowed Professorship in 2008, and the University of Florida Research Foundation Professorship in 2005. In addition, Dr. Wachsman is the Immediate Past Chair of the High Temperature Materials Division of the Electrochemical Society, Councilor of the Florida Section of the American Ceramic Society, and a member of the American Chemical Society, the International Society for Solid State Ionics, and the Materials Research Society, formerly he was an Associate Editor of the Journal of the American Ceramic Society. He has more than 140 publications and 8 patents on ionic and electronic transport in ceramics, their catalytic properties, and device performance.

Also we appointed Keith Duncan, University of Florida, as the Managing Editor of Ionics. He will basically assist Eric Wachsman in his editorship for Ionics. Dr. Keith Duncan is a Research Scientist in the Department of
Materials Science and Engineering at the University of Florida in Gainesville where he works with the Florida Institute for Sustainable Energy and the UF-DOE High Temperature Electrochemistry Center. His research includes solid oxide fuel cells, solid-state electro-catalytic reactors, gas separation membranes and the fundamental transport properties of ceramics. Dr. Duncan received his Ph.D. at the University of Florida, and previously did theoretical work on transport properties of particulate composites (at the University of the West Indies) and experimental work on superconductors at Argonne National Laboratory.

Ilse Koch will continue to handle the Editorial Office of Ionics.

Please welcome together with us Dr. Eric Wachsman and Dr. Keith Duncan in their new positions.

With best regards,

chericn Hertel

Marion Hertel, Publisher

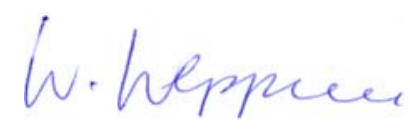

Werner Weppner, Editor-in-Chief of Ionics 